\title{
The Effect of E-Portfolio in Project-Based Learning toward Learner Autonomy and Writing Competency
}

\section{Ni Ketut Devi Ariningsih ${ }^{*}$, Luh Putu Artini2, Ni Putu Era Marsakawati ${ }^{3}$}

${ }^{123}$ Ganesha University of Education, SIngaraja, Indonesia

\begin{tabular}{l} 
A R T I C L E I N F 0 \\
\hline Article history: \\
Received 18 December \\
2020 \\
Received in revised \\
Form 06 January 2021 \\
Accepted 1 February 2021 \\
Available online 09 \\
February 2021 \\
\hline
\end{tabular}

Keywords: E-Portfolio, Project Based Learning, Learner Autonomy, Writing Competency

\begin{abstract}
A B S T R A C T
The National Education objectives can be achieved through learning process and a valid assessment process. Assessment has a strong involvement in the learning process. The purpose of this study is to investigate the effect of e-portfolio in project-based learning toward learner autonomy and writing competency experienced by X MIPA students of SMA Negeri 7 Denpasar. The research design was post-test only control group design. The research instruments used were questionnaire and writing test. Questionnaire was used to test learner autonomy, while writing test was used to test students' writing competency. Data were analyzed by employing One-way Anova and Manova. The results of this study showed that there is a significant effect of E-portfolio in Project-Based Learning toward learner autonomy and writing competency of $X$ MIPA students of SMA Negeri 7 Denpasar. The mean score of students who were taught by using e-portfolio in project-based learning strategy is higher than the mean score who were taught by using conventional strategy. E-portfolio in Project-Based Learning also revealed potentially promotes students' creativity, problem solving skills, and communication through technology skills.
\end{abstract}

\section{Introduction}

National education aims at developing the potential of students to become people who are faithful to the Almighty God, noble, healthy, knowledgeable, skilled, creative, independent, and become democratic and responsible citizens (Lukitasari, Handhika, Murtafiah, 2018; Marhaeni, Artini, Ratminingsih, Dewi, Kusuma, 2017). Those objectives have been detailed described in Peraturan Pemerintah Nomor 19 Tahun 2005 concerning National Education Standards (Marhaeni et al., 2017; Syarifah, 2019). In order to achieve those standards, it depends on how those standards collaborate in the learning process. Furthermore, the objectives can be achieved and proven through a valid assessment process, in which the assessment is carried out during the learning process. In other words, assessment has a strong involvement in the learning process. Assessment has essential and main role in teaching and learning process (Buzzetto-More, 2010; Ortega \& Minchala, 2017). Assessment is the way in assessing students' progress, giving them with feedback in order to improve their competency on the next learning process (Sardareh, 2013; Yastibas \& Yastibas, 2015). The learning process and assessment are not only a formal effort within the school framework but also are the meaningful aspects for students.

The use of alternative assessment type is an important part during learning process (Syarifah, 2019). In fact, true-false and multiple-choice used as techniques for measuring students' competency frequently. Those techniques may not provide opportunities for students in finding the answer based on their own way (Gülbahar \& Tinmaz, 2006; Hallam, Harper, McGowan, Hauville, McAllister, \& Creagh, 2008). The paradigm may not encourage the teacher to develop students' competency and carry out into authentic learning. In order to promote students' authentic learning, an appropriate learning model such as Project-Based Learning is required to be implemented. Project-based learning refers to learning activity that emphasize student-centered and merge problems in reality and practices (Gülbahar \& Tinmaz, 2006; Macías, 2012; Syarifah, 2019). Regarding to the implementation of Project-based Learning, it is important for integrating the learning model and alternative assessment-based technology, since covid-19 pandemic hit the world. One of the appropriate alternative assessments that integrate with technology is E-portfolio.

E-portfolio is also used to increase students' reflection on their learning process over time, selfassessment and self-development during the learning process (Alawdat, 2014; Chye, Liau, Liu, 2013; Hallam et al., 2008; Koraneekij \& Khlaisang, 2015). By using e-portfolio assessment, the learning process 
implies constructivism, student-centered, and authentic (Gülbahar \& Tinmaz, 2006; Mahasneh, 2020). Furthermore, students should master four basic skills in gaining English. One of those skills is writing. Writing involves process and product; the writing process embedded on grammatical, mechanical and organizational ideas in order to develop writing coherently, meanwhile product as a result of the writing process in form of text, letter, essay, and stories (Jianfeng, Raj, \& Ai, 2018; Risqiya, Pamungkas, \& Inayah, 2017; Song, 2020; Wenden, 1998).

Besides, Tonogbanua (2018) has successfully investigated the quality of formative assessment for writing through collaborative e-portfolio project; it showed that there was a positive contribution in developing writing skills and encouraging students' effort in making decisions. As proposed by Dafei (2007), the students have abilities in taking charge and responsibility for controlling their own learning. The students will know and understand the learning objectives, able to plan their learning, monitor their progress and evaluate their own learning. Therefore, the students who are autonomous will be able to obtain more in developing their competency hence they have and hold the responsibility on their own learning.

The learning strategy assisted by alternative assessment is required to facilitate the students to promote their competency in writing and develop students' autonomy. Therefore, this study aims to investigate the significant effect of E-portfolio in Project-Based Learning toward learner autonomy and writing competency of X MIPA students of SMA Negeri 7 Denpasar.

\section{Methods}

This experimental research used Post-Test Only Control Group design. There were 434 of X MIPA students as the population of the study which spread out into 11 classes. Theoretically, the flow of the design is as shown in Figure 1.

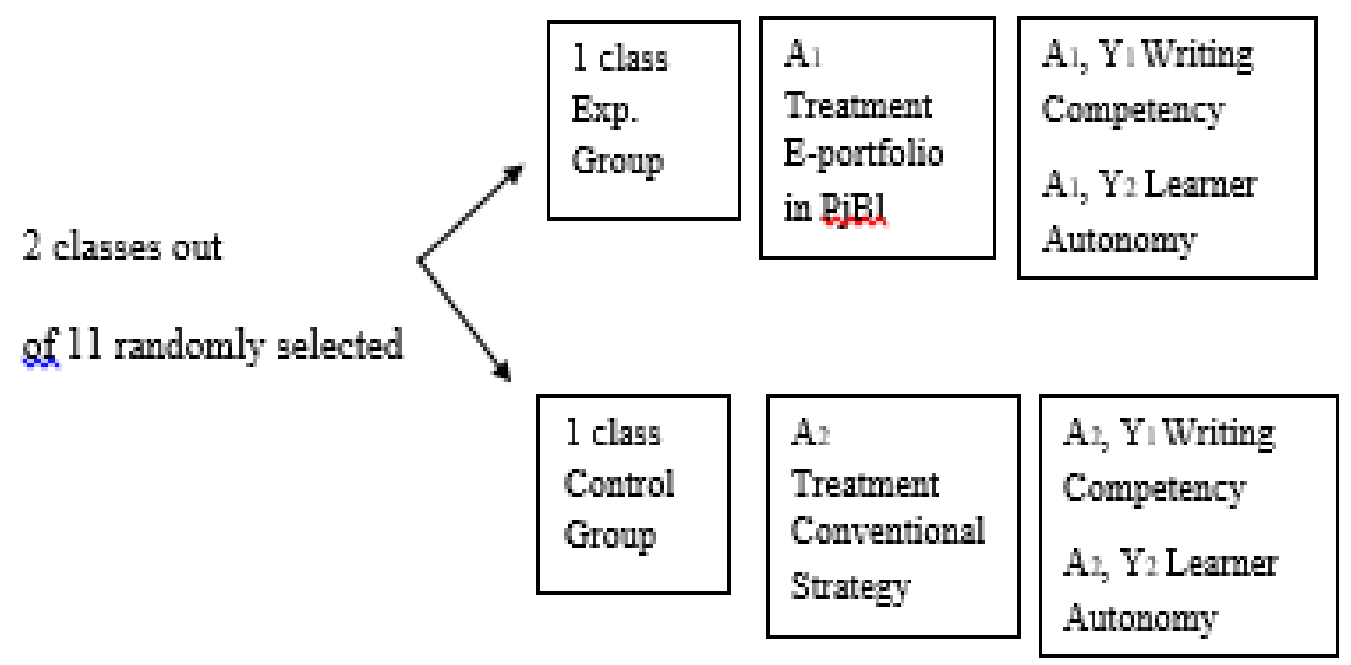

Figure 1. Research Design

In collecting the data, the two main instruments administered were the learner autonomy questionnaire and writing competency test (post-test). The questionnaire covered 43 items and the posttests were short functional text that required the students to write an announcement and simple essay in form of descriptive text and recount text. Both the questionnaire and writing competency tests underwent content validity testing from two expert judges. By using the Gregory formula analysis, the questionnaire was proven with coefficient validity 0.93 , while the writing competency tests were also proven to have with coefficient validity 1.00. Then, the reliability of the instrument was tried out, in which among the 43 items of the questionnaire, there were 40 items calculate to be valid and further analyzed the reliability using Cronbach's Alpha formula. From the calculation it was found that the questionnaire achieved very high reliability $(0.933)$.

Figure 2 shows the flow of treatment of e-portfolio in project-based learning during the learning process. In this case, there are three concepts are integrated into the treatment, including the procedures of the writing process (Harmer, 2004); project-based learning (Marhaeni, et al., 2017), and e-portfolio (Hallam et al., 2008). Based on the figure below, there are several points of project based learning assisted 
by E-portfolio in writing process such as; (1) determining, designing the project and arranging the schedule in planning process; (2) conducting the project activities assisted by collecting and selecting in drafting and editing process and (3) evaluating and presenting the project assisted by reflecting and publishing in the final version.

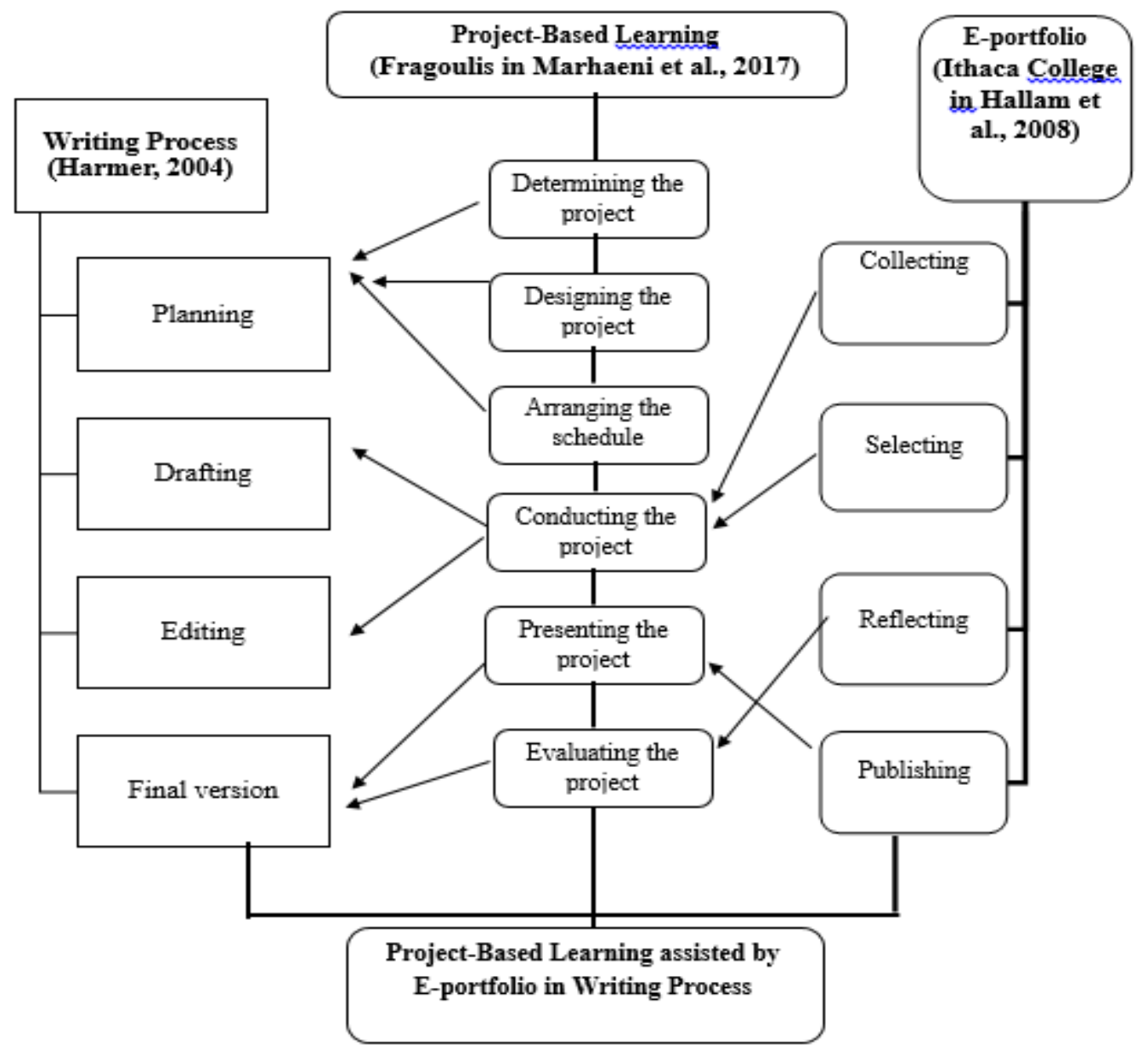

Figure 2. Project Based Learning assisted by E-portfolio in Writing Process

The data were the then analyzed through descriptive and inferential statistical analysis. Descriptive statistics analysis was used to describe the basic features of the data in this study such as mean, median, mode, range, variance and standard deviation. Meanwhile, inferential statistics analysis such as testing for normal distribution, testing for homogeneity of variance and hypothesis testing. In order to analyze the first and the second hypotheses, one-way ANOVA was used. Meanwhile, third hypothesis was tested by using Manova. In addition, the questionnaire was analyzed by using Likert Scale. This scale was used to measure the learner autonomy of X MIPA students after conducting the treatment

\section{Result and Discussion}

\section{Findings}

The findings of this study consist of the findings of central tendency and dispersion, effect of Eportfolio in Project-based Learning toward learner autonomy, effect of E-portfolio in Project-based Learning toward writing competency, and simultaneously effect of E-portfolio in Project-based Learning toward Learner Autonomy and Writing Competency. After completing all of the requirements in term of normality and homogeneity testing, the results of descriptive and inferential statistics analyze are presented below. 
Table 1. The Calculation of Central Tendency and Dispersion of both groups

\begin{tabular}{ccccc}
\hline \multirow{2}{*}{ Statistics } & \multicolumn{2}{c}{$\begin{array}{c}\text { A1 } \\
\text { Experimental Group) }\end{array}$} & \multicolumn{2}{c}{$\begin{array}{c}\mathbf{A}_{2} \\
\text { (Control Group) }\end{array}$} \\
\cline { 2 - 5 } & Y1 & Y2 & Y1 & Y2 \\
\hline Total & 3284 & 5574 & 2942 & 4453 \\
Mean & 82.10 & 139.35 & 73.55 & 111.33 \\
Std. Deviation & 4.205 & 14.179 & 1.934 & 11.641 \\
Variance & 17.682 & 201.054 & 3.741 & 135.507 \\
Minimum & 73 & 115 & 70 & 100 \\
Maximum & 90 & 192 & 78 & 140 \\
Range & 17 & 77 & 8 & 40 \\
\hline
\end{tabular}

Table 1 shows that the mean score of students' learner autonomy treated by using e-portfolio in project-based learning is 139.35. It is higher than the mean score of those treated by conventional strategy, 111.33 and the mean score of students' writing competency treated by using e-portfolio in project-based learning is 82.10 , it is also higher than the mean score of those treated by conventional strategy, 73.55. Furthermore, the following tables show the results of One-way ANOVA and MANOVA analyzes.

Table 2. Finding on the Effect of E-portfolio in Project-based Learning toward Learner Autonomy of X MIPA students

\begin{tabular}{llllll}
\hline & \multicolumn{1}{c}{$\begin{array}{c}\text { Sum of } \\
\text { Squares }\end{array}$} & df & Mean Square & F & Sig. \\
\hline Between Groups & 15708,013 & 1 & 15708,013 & 93,344 & 0,000 \\
Within Groups & 13125,875 & 78 & 168,280 & & \\
Total & 28833,88 & 79 & & & \\
\hline
\end{tabular}

As it is clearly can be seen in the table above, the value of $F=93,344$ and the significance score was 0.000. It indicates that the significance data was less than the standard (sig. $=0.000<\alpha=0.05$ ). Shortly, it can be summarized that there was a significant effect of E-portfolio in Project Based Learning toward Learner Autonomy of the X MIPA students.

Table 3. Finding on the Effect of E-portfolio in Project-based Learning toward Writing Competency of X MIPA students

\begin{tabular}{llllll}
\hline & \multicolumn{1}{c}{$\begin{array}{c}\text { Sum of } \\
\text { Squares }\end{array}$} & df & Mean Square & F & Sig. \\
\hline Between Groups & 1462,050 & 1 & 1462,050 & 136,493 & 0,000 \\
Within Groups & 835,500 & 78 & 10,712 & & \\
Total & 2297,550 & 79 & & & \\
\hline
\end{tabular}

Based on the table above, the value of $\mathrm{F}=136,493$ and the significance score was 0.000 . It means that the significance data was less than the standard (sig. $=0.000<\alpha=0.05$ ). Therefore, it revealed that there was a significant effect of E-portfolio in Project Based Learning Toward Writing Competency of the X MIPA students.

Table 4. Finding on the Effect of E-portfolio in Project-based Learning toward Learner Autonomy and Writing Competency of X MIPA students

\begin{tabular}{lllllll}
\hline Effect & & Value & F & Hypotesis & Error df & Sig. \\
\hline Intercept & Pillais Trace & 0,998 & $23812,285^{\mathrm{a}}$ & 2,000 & 77,000 & 0,000 \\
& Wilks' Lambda & 0,002 & $23812,285^{\mathrm{a}}$ & 2,000 & 77,000 & 0,000 \\
& Hotelling's Trace & 618,504 & $23812,285^{\mathrm{a}}$ & 2,000 & 77,000 & 0,000 \\
& Roy's Larges Root & 618,504 & $23812,285^{\mathrm{a}}$ & 2,000 & 77,000 & 0,000 \\
\hline Group & Pillais Trace & 0,720 & $98,839 \mathrm{a}$ & 2,000 & 77,000 & 0,000
\end{tabular}




\begin{tabular}{|c|c|c|c|c|c|c|}
\hline Effect & & Value & $\mathbf{F}$ & Hypotesis & Error df & Sig. \\
\hline & Wilks' Lambda & 0,280 & $98,839^{a}$ & 2,000 & 77,000 & 0,000 \\
\hline & Hotelling's Trace & 2,567 & $98,839^{a}$ & 2,000 & 77,000 & 0,000 \\
\hline & Roy's Larges Root & 2,567 & $98,839^{a}$ & 2,000 & 77,000 & 0,000 \\
\hline
\end{tabular}

The data gained by statistical score of Pillai's Trace, Wilks' Lambda, Hotelling's Trace and Roy's Largest Root on the table above. The score of $\mathrm{F}$ for each statistical is 23812,385 with a significance level of 0.000. Therefore, it means that simultaneously, there was a significant effect of E-portfolio in Project Based Learning toward learner autonomy and writing competency of the X MIPA students.

\section{Discussion}

From the result of finding on the effect of E-portfolio in Project-based Learning toward learner autonomy showed that the effect of the implementation of e-portfolio in project-based learning toward learner autonomy of the X MIPA students has F 93.344 with significance score of 0.000 . It means that there were differences in terms of learner autonomy ability between two groups of students who classified experimental class which was treated by e-portfolio in project-based learning and control group which was treated by conventional strategy. In addition, the descriptive statistics result in the experimental group is explained as follows; the mean of learner autonomy was 139 . 35 with a standard deviation of 14.179. Meanwhile, the descriptive analysis in the control group is showed as follows; the mean of learner autonomy was 111.33 with a standard deviation of 11.641 .

Generally, based on descriptive statistics analysis, the experimental group which was treated by using e-portfolio in project-based learning had higher learner autonomy ability than the control group which was treated by using conventional strategy. In the same line with previous research stated that eportfolio in project-based learning provide more learning opportunities to the students. The students learn to be autonomous in their personal learning, seek out advice and resolve the problems. Hence, the students tend to generate authentic and meaningful work during the learning process (Gülbahar \& Tinmaz, 2006; Mahasneh, 2020; Yastibas \& Yastibas, 2015).

Furthermore, the result of finding on the effect of E-portfolio in Project-based Learning toward writing competency showed that the effect of the implementation of e-portfolio in project-based learning toward writing competency has F 136.493 with significance score of 0.000 . This result implies that there was difference in terms of writing competency between two groups of students who classified experimental class which was treated by e-portfolio in project based learning and control group which was treated by conventional strategy. Descriptively, the mean of writing competency in the experimental group was 82.10 with a standard deviation of 4.205. Meanwhile, the mean score of students' writing competency in the control group was 73.55 with a standard deviation of 4.51.

Based on descriptive statistics analysis, the experimental group which was treated by using eportfolio in project-based learning had higher students' writing competency than the control group which was treated by using conventional strategy. In this case, e-portfolio as an assessment in project-based learning due to it is an essential part of the learning cycle that held both during and the end of projectbased learning. Similar with portfolio, e-portfolio as an alternative assessment type is widely applied for project-based learning in which its components are students' reflections, students' progress and prospective goals (Gülbahar \& Tinmaz., 2006).

The result of finding effect of E-portfolio in Project-based Learning toward learner autonomy and writing competency showed that the result of F to Pillai's Trace, Wilks' Lambda, Hotteling's Trace, Roy's Largest Root has counted as F on 23812.385 with significant of 0.000 . It can be said that, the result of F to Pillai's Trace, Wilks' Lambda, Hotteling's Trace, Roy's Largest Root were all significant, since the significant score was less than 0.05 . It can be stated that simultaneously, there was a significant effect of eportfolio in project-based learning toward learner autonomy and writing competency especially at the X MIPA students. Therefore, the implementation of e-portfolio in project-based learning has provided simultaneous effect on the improvement of learner autonomy and writing competency and it is recommended to be applied for students in order to promote their creativity, problem solving skills, and communication through technology skills.

E-portfolio is also used to increase students' reflection on their learning process over time, selfassessment and self-development during the learning process (Alawdat, 2014; Chye, Liau, Liu, 2013; Hallam et al., 2008; Koraneekij \& Khlaisang, 2015). By using e-portfolio assessment, the learning process implies constructivism, student-centered, and authentic (Gülbahar \& Tinmaz, 2006; Mahasneh, 2020). Furthermore, students should master four basic skills in gaining English. One of those skills is writing. Writing involves process and product; the writing process embedded on grammatical, mechanical and 
organizational ideas in order to develop writing coherently, meanwhile product as a result of the writing process in form of text, letter, essay, and stories (Jianfeng, Raj, \& Ai, 2018; Risqiya, Pamungkas, \& Inayah, 2017; Song, 2020; Wenden, 1998).

\section{Conclusion}

The result of the study found that there was a significant effect of e-portfolio in project-based learning toward students' learner autonomy and writing competency. E-portfolio in project-based learning can be used as an alternative teaching-learning strategy, in which it is very beneficial and innovative for assessing students' progress during the learning process. Future researches are expected to explore more deeply how to develop students' learner autonomy and improve students' writing competency. In addition, conducting different research methods and different characteristics of students can be used as different insights for further research.

\section{References}

Alawdat, M. (2014). English writing students' perspective of using e-Portfolios in the writing class. International Journal of Language and Linguistics, 2(6-3), 1-11. https://doi.org/10.11648/j.ijll.s.2014020603.11

Buzzetto-More, N. (2010). Assessing the efficacy and effectiveness of an e-portfolio used for summative assessment. Interdisciplinary Journal of e-Learning and learning Objects, 6(1), 61-85. https://www.learntechlib.org/p/44774/

Chye, S. Y., Liau, A. K., \& Liu, W. C. (2013). Student teachers' motivation and perceptions of e-portfolio in the context of problem-based learning. The Asia-Pacific Education Researcher, 22(4), 367-375. https://doi.org/10.1007/s40299-012-0022-4

Gülbahar, Y., \& Tinmaz, H. (2006). Implementing project-based learning and e-portfolio assessment in an undergraduate course. Journal of Research on Technology in Education, 38(3), 309-327. https://doi.org/10.1080/15391523.2006.10782462

Hallam, G., Harper, W., McGowan, C., Hauville, K., McAllister, L., \& Creagh, T. (2008). Australian e-Portfolio Project: ePortfolio use by university students in Australia. Australian Learning \& Teaching Council: Strawberry Hills, NSW. https://eportfoliopractice. qut. edu. au/information/report/index. jsp

Harmer, J. (2006). Review of "How to teach writing". Electronic Journal of Foreign Language Teaching, 3(2), 246-248. https://e-flt.nus.edu.sg/wp-content/uploads/2020/09/v3n22006/rev_laborda.pdf

Jianfeng, C., Raj, G. S., \& Ai, J. T. T. (2018). The Correlations among Learning Motivation, Autonomy and Language Proficiency in Chinese EFL Context. LEARN Journal: Language Education and Acquisition Research Network, 11(1), 1-14. https://eric.ed.gov/?q=learning+motivation\&id=EJ1225852

Koraneekij, P., \& Khlaisang, J. (2015). Development of learning outcome based e-portfolio model emphasizing on cognitive skills in pedagogical blended e-learning environment for undergraduate students at faculty of education, Chulalongkorn University. Procedia-Social and Behavioral Sciences, 174, 805-813. https://doi.org/10.1016/j.sbspro.2015.01.664

Lukitasari, M., Handhika, J., \& Murtafiah, W. (2018, March). Higher order thinking skills: Using e-portfolio in project-based learning. In Journal of Physics: Conference Series (Vol. 983, No. 1, p. 012047). IOP Publishing. https://doi.org/10.1088/1742-6596/983/1/012047

Macías, J. A. (2012). Enhancing project-based learning in software engineering lab teaching through an eportfolio approach. IEEE Transactions on Education, 55(4), 502-507. https://ieeexplore.ieee.org/abstract/document/6182725

Mahasneh, O. M. (2020). A Proposed Model for the University Students' E-Portfolio. Journal of Education and e-Learning Research, 7(1), 28-33. https://eric.ed.gov/?id=EJ1248214

Marhaeni, A A I N., Artini, L P., Ratminingsih, N M., Dewi, N L P E S., Kusuma, I. P. I. (2017). Asesmen Autentik dalam Pembelajaran Bahasa Inggris (1st ed.). Rajawali Pers.

Ortega, D. P., \& Minchala, O. E. (2017). Assessing Students in an Authentic and Ongoing Manner in the English Classroom. 7(3), 159-165. http://dx.doi.org/10.17507/tpls.0703.01 
Rizqiya, R., Pamungkas, M. Y., \& Inayah, R. (2017). The use of POWER learning as a learning strategy to improve students writing competency. OKARA: Jurnal Bahasa dan Sastra, 11(2), 253-262. http://dx.doi.org/10.19105/ojbs.v11i2.1491

Sardareh, A. (2013). Defining Assessment for Learning: A proposed definition from a sociocultural perspective. Life Science Journal, 10(2). https://www.academia.edu/download/51011970/Defining_Assessment_for_Learning_A_propo2 0161221-10789-1u3z6wy.pdf

Song, J. (2020). Developing English Abilities of Autonomous Learning for Undergraduates in the Environment of Ecological Affordance. English Language Teaching, 13(7), 104. https://doi.org/10.5539/elt.v13n7p104

Syarifah, E. F. (2019). Project-Based Learning To Develop Students ' Ability And Creativity In Writing Narrative. Indonesian EFL Journal, 5(1), 85-94. https://doi.org/10.25134/ieflj.v5i1.1627

Tonogbanua, J. R. (2018). Exploring collaborative e-portfolio project for teaching and learning academic writing. Asian EFL Journal Research Article, 20(12.3), 173-193. https://www.researchgate.net/profile/Jet_Tonogbanua/publication/330899341_Exploring_colla borative_E-

portfolio_project_for_teaching_and_learning_academic_writing/links/5c6c11c5a6fdcc404ebc507 0/Exploring-collaborative-E-portfolio-project-for-teaching-and-learning-academic-writing.pdf

Wenden, A. L. (1998). Metacognitive knowledge and language learning. Applied Linguistics, 19 (4), $515-537$. https://doi.org/10.1093/applin/19.4.515

Yastibas, A. E., \& Yastibas, G. C. (2015). The use of e-portfolio-based assessment to develop students' selfregulated learning in English language teaching. Procedia-social and behavioral sciences, 176, 3-13. https://doi.org/10.1016/j.sbspro.2015.01.437 